MALGORZATA CZERNICKA ${ }^{1}$

KINGA KESKA ${ }^{1}$

MAREK SZKLARCZYK ${ }^{1}$

MICHAL DZIURKA ${ }^{3}$

ANNA KOLTON ${ }^{2}$

IWONA KAMIŃSKA ${ }^{2}$

URSZULA PIENIĄŻEK ${ }^{1}$

DOROTA CHACHLOWSKA ${ }^{1}$

${ }^{1}$ Zakład Genetyki, Hodowli Roślin i Nasiennictwa, Instytut Biologii Roślin i Biotechnologii, Wydział Biotechnologii i Ogrodnictwa, Uniwersytet Rolniczy w Krakowie, Al. 29 Listopada 54, 31-425 Kraków

${ }^{2}$ Zakład Botaniki i Fizjologii Roślin, Instytut Biologii Roślin i Biotechnologii, Wydział Biotechnologii

i Ogrodnictwa, Uniwersytet Rolniczy w Krakowie, Al. 29 Listopada 54, 31-425 Kraków

${ }^{3}$ Instytut Fizjologii Roślin PAN w Krakowie, ul. Niezapominajek 21, 30-239 Kraków

Kierownik Tematu: dr Małgorzata Czernicka Zakład Genetyki, Hodowli Roślin i Nasiennictwa, Instytut Biologii Roślin i Biotechnologii, Wydział Biotechnologii i Ogrodnictwa, Uniwersytet Rolniczy w Krakowie, Al. 29 Listopada 54, 31-425 Kraków, tel.126625367, e-mail:malgorzata.czernicka@urk.edu.pl

Prace zostały wykonane $w$ ramach badan podstawowych na rzecz postępu biologicznego $w$ produkcji roślinnej na podstawie decyzji Ministra Rolnictwa $i$ Rozwoju Wsi nr HOR.hn.802.8.2018, Zadanie 98.

\title{
Analiza wpływu hipoksji na zwiększenie tolerancji na stresy u pomidora (Lycopersicon esculentum L.) i ogórka (Cucumis sativus L.)
}

Analysis of the effects of exposure to hypoxia on increase stress tolerance at tomato (Lycopersicon esculentum $\mathbf{L}$.) and cucumber (Cucumis sativus $\mathbf{L}$.)

Słowa kluczowe: hipoksja, ogórek, pomidor, stres, zalanie

\section{CEL BADAŃ}

W hodowli roślin znany jest proces wzbudzania odporności roślin poprzez działanie czynnikiem stresowym o umiarkowanej intensywności. Celem zadania badawczego jest zastosowanie stresu obniżonego stężenia tlenu w glebie (hipoksji) w stadium rozsady do uaktywnienia mechanizmów odporności (tolerancji) na czynniki środowiskowe u pomidora i ogórka. W 2018 roku zrealizowano dwa tematy badawcze, tj. (1) Analiza genetycznych, biochemicznych i fizjologicznych podstaw odpowiedzi różnych genotypów pomidora i ogórka na hipoksję, (2) Ocena efektywności działania stresu 
hipoksji w stadium siewki na zwiększenie odporności roślin na stres obniżonego stężenia tlenu w glebie. Celem podjętych badań była ocena wpływu hipoksji w obrębie systemu korzeniowego pomidora i ogórka na morfologię roślin, na aktywność wybranych związków o charakterze antyoksydacyjnym i aktywność fotosyntetyczną, na akumulację fitohormonów (auksyn, cytokinin, kwasu abscysynowego i prekursora etylenu - ACC), ekspresję genów i wybranych białek. Ponadto cel badań stanowiło porównanie dynamiki wzrostu roślin oraz wielkości i jakości plonu owoców pomidora i ogórka traktowanych i nietraktowanych stresem hipoksji w fazie rozsady.

\section{MATERIAŁ I BADANIA}

Obiektami badań były 2 genotypy pomidora oraz 2 linie DH ogórka. Rośliny po osiągnięciu stadium 2-4 liści właściwych podzielono na 3 grupy roślin:

1. pierwsza grupa (kontrolna) uprawiana była bez zastosowania warunków stresowych,

2. druga grupa (oznaczona jako $1 \times \mathrm{H}$ ) została potraktowana stresem obniżonej zawartości tlenu w obrębie systemu korzeniowego poprzez zalanie wielodoniczek wodą przez okres 7 dni,

3. trzecia grupa (oznaczona jako $2 \times \mathrm{H}$ ) została potraktowana stresem hipoksji poprzez zalanie przez okres 7 dni, po czym po 14 dniach od ustania warunków stresowych rośliny z tej grupy ponownie poddane zostały hipoksji przez kolejne 7 dni.

\section{WYNIKI BADAŃ}

Wyniki dotyczące oceny cech morfologicznych badanych obiektów pomidora i ogórka wskazują na zróżnicowaną odpowiedź genotypów na stres zalania. Wykazano zróżnicowanie międzygenotypowe oraz międzygatunkowe. U pomidora siedmiodniowy stres zalania spowodował wolniejszy przyrost roślin genotypu wrażliwego na stres ograniczonego dostępu tlenu. Z kolei u badanych linii DH ogórka na skutek 7 dni stresu nie wykazano zróżnicowania $\mathrm{w}$ wysokości roślin kontrolnych i roślinami poddanymi stresowi zalania. Różnicę w wysokościach roślin ogórka zaobserwowano dopiero po 28 dniach trwania doświadczenia, gdzie wysokość roślin potraktowanych podwójnie stresem hipoksji była znacznie niższa w stosunku do roślin kontrolnych. Świeża masa części nadziemnej roślin badanych genotypów pomidora i ogórka zwiększała się wraz czasem trwania doświadczenia. W przypadku obiektów wrażliwych na stres zalania, stwierdzono większą masę roślin nietraktowanych stresem w porównaniu do roślin zalanych przez okres 7 dni. Zaobserwowano tworzenie się korzeni bocznych zarówno u pomidora, jak i ogórka u roślin poddanych stresowi zalania. U pomidora więcej korzeni bocznych zaobserwowano u genotypu określonego jako wrażliwy, natomiast w przypadku ogórka u genotypu tolerancyjnego na stres hipoksji.

Na podstawie analizy zawartości dwóch związków o charakterze antyoksydacyjnym, tj. kwasu askorbinowego i glutationu stwierdzono, że zastosowane warunki hipoksji wpływają na zmiany w układzie antyoksydacyjnym roślin pomidora i ogórka. Zawartość glutationu zmieniła się u roślin tolerancyjnych na stres zalania poddanych dwukrotnie 
stresowi, tj. wzrosła u pomidora, a zmniejszyła się u ogórka, co wskazuje to wyraźnie na odmienne reakcje roślin o wyższej i niższej wrażliwości na stres hipoksji. W przypadku badanych genotypów ogórka i pomidora nie zaobserwowano istotnych statystycznie zmian w zawartości kwasu askorbinowego.

W wyniku analizy fitohormonów u pomidora stwierdzono dwukrotnie wyższą zawartość auksyn (IAA i IBA) w liściach pomidora wrażliwego na hipoksję. Spośród wolnych cytokinin największą akumulację w liściach wykazała cis-zeatyna (c-ZEA). U obydwu genotypów pomidora zaobserwowano akumulację ABA w liściach po 48 godzinach od zalania roślin jednokrotnie. W efekcie drugiego zalania po 48 godzinach stwierdzono najniższą zwartość ABA, ale tylko u genotypu tolerancyjnego na hipoksję. Wzrost poziomu ACC w liściach stwierdzono po 24 godzinach od pierwszego zalania roślin u genotypu tolerancyjnego na stres zalania.

W oparciu o immunodetekcję wybranych białek w warunkach hipoksji w korzeniach pomidora stwierdzono obecność dehydrogenazy alkoholowej (ADH) wyłącznie u roślin traktowanych stresem hipoksji. Wyższą akumulację ADH zarejestrowano u wrażliwego na stres hipoksji obiektu, a powtórna hipoksja nie zintensyfikowała akumulacji ADH. Z kolei tolerancyjny na hipoksję obiekt pomidora cechowała niższa akumulacja białka Rap2.12 stanowiącego czynnik transkrypcyjny biorący udział w aktywacji ekspresji genów odgrywających kluczową rolę w aklimatyzacji roślin na stres hipoksji.

Zsekwencjonowanie transkryptomów związanych z regulacją ekspresji genów (mikroRNA) aktywowanych pod wpływem hipoksji u dwóch obiektów pomidora pozwoliła zidentyfikować od 258 do 314 cząsteczek miRNA, z czego tylko 95 były to cząsteczki miRNA opisane w bazie MiRBase dla pomidora. Szczegółowa analiza poziomów ekspresji miRNA pozwoliła wskazać cząsteczki miRNA specyficzne dla obiektu tolerancyjnego na hipoksję oraz wrażliwego genotypu. Stwierdzono większą liczbę miRNA o zróżnicowanej ekspresji dla roślin poddanych dwukrotnemu zalaniu. Wśród transkryptów regulowanych przez cząsteczki miRNA zidentyfikowano transkrypty kodujące białka związane z mechanizmami odpowiedzi na stres hipoksji.

Analiza poziomu ekspresji transkryptów zidentyfikowanych in silico u dwóch genotypów ogórka w warunkach hipoksji wykazała różnice w ekspresji badanych genów pomiędzy roślinami nietraktowanymi a traktowanymi stresem hipoksji. Stwierdzono również różnice we względnym poziomie ekspresji genów między badanymi liniami DH ogórka. Genotyp wrażliwy ogórka charakteryzował się zwiększoną aktywnością genu dehydrogenazy alkoholowej związanej z przekształceniem aldehydu do etanolu, przy jednoczesnej oksydacji $\mathrm{NADH}$ do $\mathrm{NAD}^{+}$. Na podstawie analizy ekspresji genu kodującego długołańcuchową syntazę acylo-CoA (lacs) można wnioskować, że linia ogórka toleranycjna na stres hipoksji uruchamia intensywnie mechanizmy związane $\mathrm{z}$ aktywnością systemu antyoksydacjnego. Stwierdzono różnice w poziomie ekspresji genu oksydazy 1-aminocyklopropano-1-karboksylanu (aco) w odpowiedzi na stres hipoksji u badanych linii ogórka wykazujących się przeciwstawną reakcją na ograniczony dostęp tlenu, co świadczy o zróżnicowanym mechanizmie związanym z odpowiedzią na ww. stres. 
W wyniku porównania dynamiki wzrostu roślin oraz wielkości i jakości plonu owoców pomidora i ogórka traktowanych i nietraktowanych stresem hipoksji w stadium rozsady stwierdzono zróżnicowanie międzygenotypowe i międzygatunkowe w odpowiedzi na stres hipoksji u roślin pomidora i ogórka w fazie owocowania. Potraktowanie roślin ogórka linii wrażliwej stresem hipoksji w fazie rozsady spowodowało uzyskanie większego plonu w porównaniu do roślin nietraktowanych stresem. Podwójny stres hipoksji w fazie rozsady spowodował zmniejszenie zawartości kwasu askorbinowego w owocach pomidora i zwiększenie zawartości cukrów rozpuszczalnych u linii ogórka wrażliwej na badany stres. 